\title{
Economic weights for Holstein Friesian traits in South Africa
}

\author{
Mariëtte du Plessis and C.Z. Roux \\ Department of Genetics, University of Pretoria, Pretoria, 0002 South Africa \\ Received 1 May 1998; accepted 16 July 1998
}

\begin{abstract}
In this study economic weights for production and functional traits of the Holstein Friesians in South Africa were calculated using a simulation model. The production traits were milk, butterfat, protein and lactose yield and the functional traits included feed efficiency, survival rate, calving interval and live weight. The simulation model was developed for three production systems and made use of two South African milk price systems to calculate the economic weights. In both price systems the feed efficiency had the largest economic weight, followed by the four production traits. The economic weights of the other functional traits were much smaller than the economic weights of the production traits.
\end{abstract}

In hierdie studie is ekonomiese gewigte vir produksie en funksionele eienskappe van die Holstein Friese in Suid-Afrika bereken met behulp van 'n simulasiemodel. Die produksie-eienskappe was melk-, bottervet-, protein-, en laktose-opbrengs, en die vier funksionele eienskappe was oorlewingstempo, liggaamsmassa, kalfinterval en voerdoeltreffendheid. Die simulasiemodel was vir drie produksiesisteme ontwikkel en het twee Suid-Afrikaanse melkpryssisteme gebruik om die ekonomiese gewigte te bereken. In beide sisteme was die ekonomiese gewig vir voerdoeltreffendheid die grootste, gevolg deur die vier produksie-eienskappe. Die ekonomiese gewigte van die ander drie funksionele eienskappe was heelwat kleiner as die ekonomiese gewigte van die produksie-eienskappe.

Keywords: Economic weights, Holstein-Friesians, South Africa

\section{Introduction}

A major advance in selection theory occurred when Smith (1937) and Hazel (1943) constructed the selection index. It is expected that the selection index, in comparison with tandem selection and selection with independent culling levels, will attain the maximum improvement of the economic value. Index selection is the simultaneous selection for economically important traits, where appropriate weights are given to each trait, according to the relative economic importance, its heritability and the genetic and phenotypic correlations between the different traits. Thus the index gives the best linear prediction of an individual's breeding value, by determining the values of the weighting factors so that the correlation, $r_{\mathrm{IA}}$, between the index and breeding value is maximized.

Animals vary in breeding value for each of the economically important traits. Therefore, the aggregate value of an animal is the sum of its trait genotypes, each genotype being weighted according to the relative economic value of that trait. Hazel (1943) defined the relative economic weight of a trait as the net increase in profit of the production system for each unit of improvement of the trait.

Gibson et al. (1992) evaluated the sensitivity of economic weights to several economic factors including parameter values and the pricing system of milk components. The economic weights and 
therefore the resulting selection index were only sensitive to one factor, namely, the pricing system of the milk components. Since the pricing systems differ between countries, each country could have a unique set of economic weights. Therefore the objective of the study was to calculate economic weights for production and functional traits of Holstein-Friesians using milk-pricing systems specific for South Africa.

\section{Materials and methods}

Economic weights can be derived from the multiple regression equation $H=a_{1} A_{1}+a_{2} A_{2}+\ldots+$ $a_{n} A_{n}$ which represents the aggregate value of the animal, where $a_{i}$ equals the economic weight of the trait and $A_{i}$ the genetic value of the animal for the trait. This involves the estimation of the genetic (co)variances for which it may be difficult to obtain accurate estimates. It may also be difficult to evaluate $\mathrm{H}$ for individual animals. Owing to these difficulties researchers use modeling methods to calculate economic weights of dairy breeds.

According to Weigel et al. (1995) the modeling methods to derive economic weights can be divided into simulation, dynamic programming and profit functions. This study made use of simulation modeling to calculate the economic weights, since simulation modeling offers the potential for more detailed and mechanistic understanding of the relationship between breeding and production (Harris \& Newman, 1994).

Harris \& Freeman (1993) subdivided simulation modeling into positive (data analysis) and normative (bio-economic modeling) methods. For this study a combination of the two methods was used. Certain elements of the model were estimated or assumed according to scientific research and management principles. Production elements, such as the feed intake correlated with milk production, cannot be estimated accurately and field data must therefore be used. According to research carried out on sensitivity of economic weights by Gibson et al. (1992), it can be assumed that random price fluctuations across years will have an insignificant effect on the economic weights, when economic weights are scaled to the present values by using the estimated inflation rate.

For the calculation of economic weights the economic efficiency ratio (returns divided by expenses) was recommended by Smith et al. (1986). The use of the economic efficiency, instead of profit, makes the calculated economic weights independent of the enterprise size, so that rescaling for enterprise size is unnecessary.

\section{The simulation model}

The model was developed in Microsoft Excel of Windows 95 and included three production enterprises. These production enterprises were classified according to the production level of the herds. The low production enterprise had an average of $6000 \mathrm{~kg}$ milk per lactation, the medium production enterprise $8000 \mathrm{~kg}$ per lactation and the high production enterprise an average of $10000 \mathrm{~kg}$. The data input given below was used in the model:

\section{Herd composition}

The model assumed a constant herd size of 100 lactating cows. The lactating cows were culled after the fifth lactation. The distribution of the lactating cows was calculated using the reasoning of Roux (1992) and information on the cow distributions in South Africa from Loubsher \& Rautenbach (1994).

The study's minimum intercalving period was 365 days. Taking the minimum intercalving period as a proportion of the actual intercalving period gave the calving percentage. All the bull calves born were sold at market price. All the one-year-old heifers were kept, while the two-year- 
old heifers, not used for replacement, were sold.

\section{Diets and their composition}

The study used a total mixed ration (TMR) strategy combined with group feeding. The lactating cows were divided into five feeding groups according to their lactation number, production level and stage of pregnancy. The dry cows were fed with a separate TMR for their specific nutritional needs. The heifers were also fed with a TMR from the age of six months.

The different rations were obtained from a sampling of farmers in the Heidelberg-Standerton area. The nutritional adequacy of the rations was evaluated using the feed tables of NRC (1988) and Stewart \& Dugmore (1995). Information from the farmers was used to determine the dry matter intake of the different groups.

\section{Expected milk production for a 300 day lactation period}

The average production of the farmers that took part in the project, as calculated by the ARC (1996), was used for this input.

\section{Prices and quantities of production supplies}

Information on production requirements was obtained from the Sensitivity Analyses of Milk Production (SAMP) Program of the South African Milk Producers' Organisation. This included fixed costs, veterinary expenses and other production expenses.

\section{The South African milk price systems}

The milk price was determined by protein to butterfat ratio, milk yield of the herd as well as other factors including transport costs, somatic cell count and total bacterial count.

The model used the above input values to calculate the feeding, replacement and veterinary costs as well as production costs. The herd income consisted of sales from livestock and milk. This resulted in three, 365 day production period budgets, one for each of the production enterprises. From the budgets the economic efficiency ratio (income divided by expenses) was calculated.

\section{Calculation of economic weights}

Before the economic weights were calculated, the unit of measurement for each trait was chosen, on the basis of the general application of the unit by the industry. Table 1 gives the units in which each trait was measured.

The economic weight of a trait was calculated by determining the effect of a unit change on the economic efficiency. For this calculation the other trait values were kept constant. Table 2 summarizes the different elements of the budget influenced by the trait changes.

Owing to the inconsistent results of the influence of the diet on milk protein production (Kennelly, 1993 and Holter et al., 1997), the economic weight of protein yield was calculated with and without dietary manipulation. This would determine if there will be any possible change in the economic weight of protein yield.

To calculate the economic weights, the study concentrated on two of the major milk price systems used in South Africa. The first price system was used by a milk buyer who has fresh milk and yogurt as main products, while the second price system came from a milk buyer with cheese and butter as his main products. 
Table 1 Units used for trait measurements

\begin{tabular}{ll}
\hline Trait & Unit \\
\hline Milk yield & $\mathrm{kg} / \mathrm{cow} /$ day \\
Butterfat yield & $\mathrm{kg} / \mathrm{cow} / \mathrm{day}$ \\
Protein yield & $\mathrm{kg} / \mathrm{cow} /$ day \\
Lactose yield & $\mathrm{kg} / \mathrm{cow} /$ day \\
Survival rate & $\%$ survival from lactation $\mathrm{i}^{1}$ to $\mathrm{i}+1$ \\
Live weight & $\mathrm{kg}$ \\
Feed efficiency & $\mathrm{MJ}$ milk energy/MJ ME/day \\
Calving interval & $\mathrm{day}$ \\
\hline i i equals lactation number
\end{tabular}

Table 2 Summary of the elements from the budget influenced by the trait changes

\begin{tabular}{|c|c|c|c|c|c|c|}
\hline Trait & Fixed costs & Feed costs & Cull rate & Marketing costs & Milk price & $\begin{array}{l}\text { Income from } \\
\text { livestock sales }\end{array}$ \\
\hline Milk yield & + & +1 & & & + & \\
\hline Butterfat yield & & + & & & + & \\
\hline Protein yield & & + & & & + & \\
\hline Protein yield & & & & & + & \\
\hline Lactose & & & & & + & \\
\hline Survival rate & & + & $-^{2}$ & - & & - \\
\hline Feed efficiency & & - & & & & \\
\hline Live weight & & \pm & & \pm & & \pm \\
\hline Calving interval & & + & & + & & + \\
\hline
\end{tabular}

$1+$ equals an increase in the specified cost/income; ${ }^{2}$ - equals a decrease in the specified cost/income

\section{Results and discussion}

The economic weights calculated by dividing the change in economic efficiency by the trait change and then multiplying the answer by 100 for the two price systems are presented in Tables 3 and 4.

In both price systems feed efficiency had the largest economic weight, followed by the four production traits. The economic weights of the other functional traits were smaller than those of the production traits. The economic weights were all positive except live weight, which had a small negative value.

In the price system for fresh milk and yogurt the economic weight of protein and butterfat yield was largest followed by that of milk yield. The economic weight of lactose yield was the smallest of the production traits. This order of the economic weights changed in the milk price system for cheese and butter. In this system the economic weight for lactose yield was larger than that of milk yield, while the economic weights of butterfat and protein yield were the largest.

These calculated economic weights can be substituted for the $a_{i}$ values in the merit equation of Falconer (1990), namely: $H=a_{1} A_{1}+a_{2} A_{2}+\ldots+a_{n} A_{n}$. The potential of a trait in selection can be 
Table 3 Economic weights for production and functional traits of Holstein Friesians using a milk price system for fresh milk and yogurt

\begin{tabular}{lccc}
\hline & Low $(\approx 6000 \mathrm{~kg})^{3}$ & Medium $(\approx 8000 \mathrm{~kg})$ & High $(\approx 10000 \mathrm{~kg})$ \\
\hline Production traits & & & \\
Milk yield & 3.69 & 3.03 & 2.64 \\
Butterfat yield & 24.9 & 24.6 & 21.2 \\
Protein yield without feed $\Delta^{1}$ & 56.8 & 43.9 & 35.4 \\
Protein yield with feed $\Delta^{2}$ & 20.8 & 17.6 & 9.42 \\
Lactose yield & 3.64 & 2.91 & 2.38 \\
Functional traits & & & \\
Survival rate & 0.178 & 0.146 & 0.135 \\
Feed efficiency & 184 & 179 & 151 \\
Live weight & -0.0860 & -0.0988 & -0.0928 \\
Calving interval & 0.0107 & 0.0160 & 0.0300 \\
\hline I Economic weight calculated without feed manipulation; ${ }^{2}$ Economic weight calculated with feed \\
manipulation; ${ }^{3}$ Average production per lactation of each enterprise given in parenthesis
\end{tabular}

Table 4 Economic weights for production and functional traits of Hotstein Friesians using a milk price system for cheese and butter

\begin{tabular}{lccc}
\hline & Low $(\approx 6000 \mathrm{~kg})^{3}$ & Medium $(\approx 8000 \mathrm{~kg})$ & High $\approx 10000 \mathrm{~kg})$ \\
\hline Production traits & 3.92 & 3.15 & 2.74 \\
Milk yield & 21.2 & 21.9 & 19.2 \\
Butterfat yield & 52.3 & 40.4 & 32.5 \\
Protein yield without feed $\Delta^{1}$ & 13.9 & 12.5 & 6.54 \\
Protein yield with feed $\Delta^{2}$ & 11.8 & 9.32 & 7.62 \\
Lactose yield & & & \\
Functional traits & 0.081 & 0.153 & 0.141 \\
Survival rate & 197 & 192 & 161 \\
Feed efficiency & -0.0932 & -0.106 & -0.0990 \\
Live weight & 0.0147 & 0.0193 & 0.0340 \\
Calving interval & Economic weight calculated without feed manipulation; ${ }^{2}$ Economic weight calculated with feed \\
'Echipulation; ${ }^{3}$ Average production per lactation of each enterprise given in parenthesis
\end{tabular}

calculated by $a_{i} C R_{i}$, where the equation for the correlated response $\left(C R_{i}\right)$ of a trait to the selection index is given by Falconer (1990). Such a comparison of the traits is not yet possible owing to incomplete information on genetic and phenotypic (co)variances. Further research in this field should include the estimation of genetic and phenotypic (co)variances as well as the calculation of economic weights of other dairy breeds in South Africa.

\section{References}

ARC, 1996. Breed \& herd averages: SA Holstein Frieslands. National Dairy Cattle Performance Testing 
Scheme: South Africa 15.

FALCONER, D.S., 1990. In: Introduction to quantitative genetics 3rd edition. Longman Scientific \& Technical, England.

GIBSON, J.P., GRAHAM, N. \& BURNSIDE, E.B., 1992. Selection indexes for production traits of Canadian dairy sires. Can. J. Anim. Sci. 72, 477.

HARRIS, B.L. \& FREEMAN, A.E., 1993. Economic weights for milk yield traits and herd life under various economic conditions and production quotas. J. Dairy Sci. 76, 868.

HARRIS, L.H. \& NEWMAN, S., 1994. Breeding for profit: Synergism between genetic improvement and livestock production. J. Anim. Sci. 72, 2178. (Review)

HAZEL, L.N., 1943. The genetic basis for constructing selection indexes. Genetics 28, 476.

HOLTER, J.B., WEST, J.W. \& McGILLIARD, M.I., 1997. Predicting ad libitum dry matter intake and yield of Holstein cows. J. Dairy Sci. 80, 2188.

KENNELLY, J.J., 1993. The untapped potential to alter the composition of milk by dietary means. Advances in Dairy technology 5, 105. Proc. Western Can. Dairy Seminar. Dept. Anim. Sci., Univ. Alberta, Edmonton, Canada.

LOUBSHER, L.F.B. \& RAUTENBACH, L., 1994. Longevity of Holstein Frieslands and Jerseys in the RSA. National Dairy Animal Performance and Progeny Testing Scheme: Annual report 14, pp. 20.

NRC, 1988. In: Nutrient requirements of dairy cattle 6 th rev. edition. National Research Council (U.S.A.). Subcommittee on dairy cattle nutrition. National Academy of Sciences, Washington pp. 35.

ROUX, C.Z., 1992. Maximum herd efficiency in meat production I: Optima for slaughter mass and replacement rate. S. Afr. J. Anim. Sci. 22, 1.

SMITH, H.F., 1937. A discriminant function for plant selection. Ann. Eugen. 7, 240.

SMITH, C., JAMES, J.W. \& BRASCAMP, E.W., 1986. On the derivation of economic weights in livestock improvement. Anim. Prod. 43, 545.

STEWART, P.G. \& DUGMORE, T.J., 1995. Nutrient requirements of dairy cattle. In: Dairying in KwazuluNatal. Ed. Dugmore, T.J., Department of Agriculture, South Africa, pp. 183.

WEIGEL, D.J., CASSELL, B.G., HOESCHELE, I. \& PEARSON, R.E., 1995. Multiple-trait prediction of transmitting abilities for herd life and estimation of economic weights using relative net income adjusted for opportunity cost. J. Dairy Sci. 78, 639. 